Љубица Д. Весић*

Универзитет у Београду

Учитељски факултет

https://doi.org/10.18485/ai_fonefonosj.2020.ch13

811.163.41'342.9

\title{
О УПОТРЕБИ ФОНЕТСКИХ ДУБЛЕТА У САВРЕМЕНОМ ЈЕЗИКУ
}

Дублетни облици честа су појава и у фонетском систему српског језика. Обично се јављају у оквиру гласовних алтернација, али и у вези с изговором гласа Х. У Правопису Матице српске (2010), као дублетни облици наводе се и неки које би један број говорника сматрао необичним, па можда и архаичним. Дублети често у говору могу изазвати несигурност, те је због тога основни циљ рада приказати категорије у којима се они „по правилу" јављају и преиспитати њихов положај у систему: да ли је увек оправдано имати два облика и да ли се може утврдити којим облицима треба дати предност или их сматрати јединим исправним у савременом говору.

Кључне речи: фонетика, гласовне алтернације, гласовне промене, дублети, норма српског језика.

\section{Увод}

Као и у другим језичким подсистемима, дублетни облици честа су појава и у фонетском систему српског језика. Дублетни облик је „једна од двеју варијаната неке речи које се међу собом разликују морфолошки, гласовно или акценатски" (ЕРСЈ). У фонетици обич-

* ljubica.vesic@uf.bg.ac.rs 
но се јављају у оквиру гласовних алтернација, али и у вези са изговором гласа Х. Дублетизам настаје као последица необавезног вршења гласовних алтернација. За разлику од гласовних промена које су се вршиле без изузетка где је било услова, гласовне алтернације се не врше увек јер, како се наводи, „језичко осећање води рачуна и о лакоћи изговора и о чувању основног облика да се не помути значење лексеме" (Стакић 2010: 16). Код појединих речи јављају се напоредо два облика - један у ком се алтернација јавља и други у ком алтернација изостаје.

Велики број дублета не мора нужно олакшати говорницима избор одређеног облика. Често је управо супротно. Дублети „начелно нису пожељни у књижевном (стандардном) језику јер својим присуством дезавуишу кодификацију, којом се, зна се, осигурава једнообразност норме за све кориснике" (Ћорић 2009: 85). Иако велики број дублета може изазвати колебање и несигурност, они не морају представљати баласт у језику. Језик је склон променама, стално је у превирању, те се дублети могу сматрати нормалном појавом, а избором варијаната осликавају и богатство језика. (Ћорић 2009: 85; Јокановић Михајлов 2012: 243).

Међутим, Правопис српског језика Матице српске (2010) као дублетне наводи и неке облике које би један број говорника засигурно сматрао необичним, па можда чак и архаичним (ајвар - хајвар, кониерат - концерт). Због тога је основни циљ овог рада приказати категорије у којим се дублетни облици „по правилу” јављају и преиспитати њихов положај у систему. У ту сврху спровели смо истраживње које је обухватило анализу савремених нормативних приручника: Правописа из 2010. и Речника српског језика из 2011, али и Правописа из 1960. Постојање различитих варијаната 
које су конкурентске подразумева и преовладавање једне, док се друга или губи, или специјализује за посебну нијансу значења (Јокановић Михајлов 2012: 242). Вођени том идејом, желели смо да испитамо да ли је у свим примерима оправдано имати два облика и да ли је могуће тек тако један облик прогласити неправилним, као и начин на који се може утврдити којим облицима треба дати предност или их сматрати јединим исправним у савременом говору. Примере смо ексцерпирали из новог правописа, а затим смо анализирали начин њихове обраде у другим приручницима. Истраживање је обухватило и анализу анкете у којој су учествовале три групације младих људи: ученици основних и средњих школа и студенти. Испитаници су у задацима наводили тражени облик речи, тако што су се, од могућа два, опредељивали за онај облик који је њима природнији и ближи њиховом језичком осећању.

Анализирајући Правопис, издвојили смо алтернације у којима се јавља највећи број дублетних облика - алтернација $\kappa: \mathcal{u}, 2: \mathcal{*}$ и $x: \mathcal{u}$, алтернација $\kappa: \mathcal{u}, 2: 3$ и $x$ $: c$, алтернација $o: e$ и алтернација $a: \emptyset$ и изговор гласа $x$.

Алтернација $\kappa: ч, z: \mathcal{* ~ и ~} x: \mathcal{w}$

У речнику који прати Правопис сви примери за дублетне облике у којима се јавља ова алтернација јесу примери деминутива, односно хипокористика изведених суфиксом - ица и један пример присвојног придева изведеног суфиксом -ин (свастикин/свастичин). 


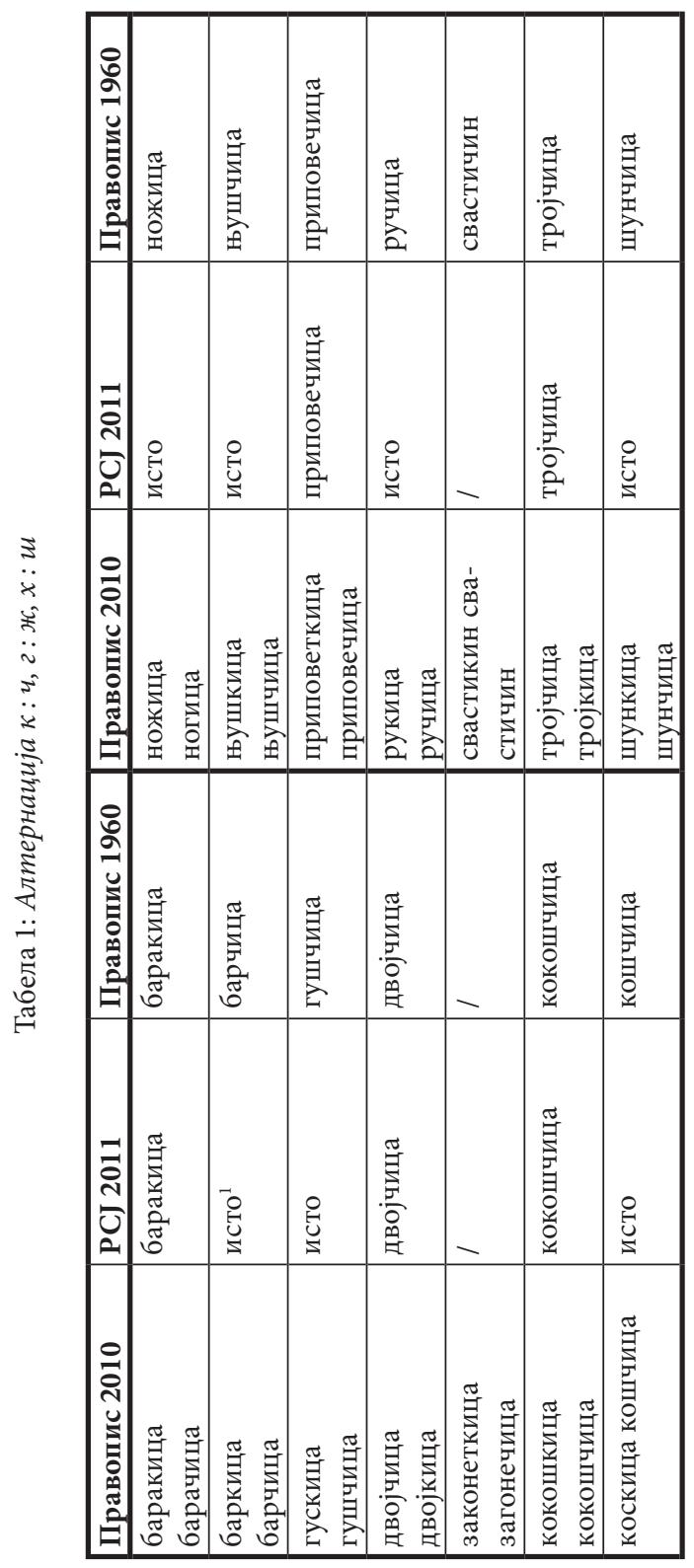

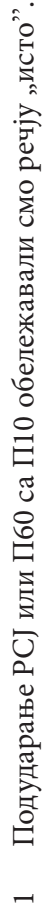


Ако наведене примере упоредимо са П60, видимо да је у старијем издању ситуација била другачија. У П60 није било недоумица - јављају се само облици са алтернацијом ${ }^{2}$. Ниједан од наведених примера нема дублетне облике. Иако се, обично, дублетни облици временом сведу на један облик (или опстају оба са разликама у значењу), у П10 десило се управо супротно - њихов број се повећао. Речник српскога језика (2011) стоји између ових двају правописа. Дублетни облици постоје, али их је мање: баркица/барчица, гускица/гушчица, ко-

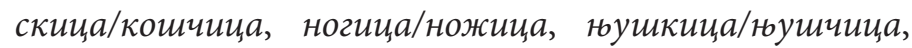
рукииа/ручица и шункица/шунчица. Остали примери наведени су или са алтернацијом (двојчица, кокоччиu, приповечииа, тројчица) или без ње (баракища), а поједине речи се уопште не јављају као одреднице. Не можемо са сигурношћу тврдити на основу ког се критеријума неки примери јављају са алтернацијом, а неки без ње. Свакако је занимљиво да се у РСЈ јавља само облик баракица, а њему сличан по гласовном саставу баркица/барчища, као дублетни. Било би очекивано и да се за деминутив именице приповетка јаве дублетни облици због додатне алтернације $(m: ø)$, међутим, као једини облик прихвата се приповечица.

Накнадно увођење дублетних облика у стандардни језик чини се оправданим, јер међу говорницима заиста постоје колебања при употреби наведених речи. То су показали и резултати нашег истраживања. У већини примера испитаници су се опредељивали за облик у ком се не јавља алтернација - баракица, баркица, гускиц, а, загонеткица, кокошкица, юушкица и шункица, док су се у другим опредељивали за облик са алтернацијом: тројчица, ручища и двојчица. У два примера резулта-

2 У П60 нема примера загонеткийа/загонечиияа. 
ти су били готово истоветни за оба облика: ногица/ ножица, коскиияа/кошчица. Примећује се да се у оним речима у којима би алтернација довела до евентуалног замагљења значења мотивне речи испитаници чешће опредељују за облик без алтернације. Примери тројчии, ручииа и двојчииа се могу објаснити тиме што су питању фреквентније лексеме (посебно за нашу групу испитаника, сачињену од ђака и студената). Занимљиво је да се код примера ногииа/ножица истоветан број испитаника одлучио или за један или за други облик, а очекивало се да ће се, аналошки према примеру ручица, већина одлучити и за облик ножица. Дати резултати показују да је, у овом случају, језик у фази превирања, и да ће бити потребно још неко време да се издвоји тај један облик који ће однети превагу над другим. Друга могућност је свакако да се задрже оба облика међу којима ће постојати семантичка диференцијација, о чему се у литератури већ говори: „рукииа и ногииа се све чешће осећају као хипокористици, док је ручиияа 'оно што се држи у руци', ножица је 'део намештаја у стола, столице и сл."” (Стакић 2010: 15). Једини пример у ком би се две варијанте могле свести на једну јесте шункииа/иунчица. Облик жунчии, јавио се у истраживању тек код два испитаника, те би се могао означавати као редак или неуобичајен. 


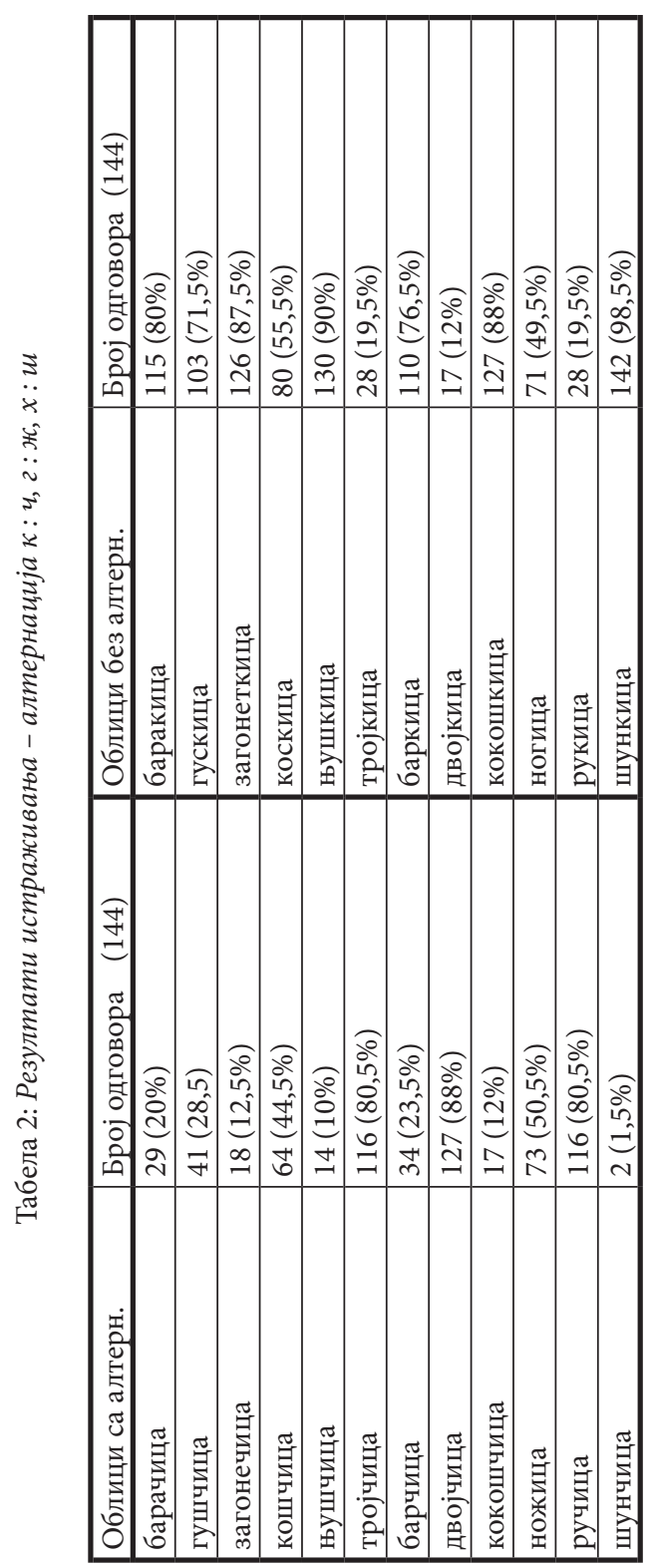


Алтернација $\kappa: u, z: 3$ и $x: c$

Због великог броја изузетака али и дублетних облика, алтернација $\kappa: u_{,}, 2: 3$ и $x: c$ може бити веома проблематична за говорнике српског језика, те се она често јавља тамо где јој, према норми, није место (журиц ум. журки), или изостаје тамо где је треба употребити (банки ум. банци). У П10 издвојили смо 74 дублетна облика. Сви они се везују за категорију датива и локатива једн. именица женског граматичког рода које се у номинативу једнине завршавају на $-a$, што потврђује ставове других аутора да „у облицима датива и локатива једнине именица женског рода на - $а,-2 a$ и -хa не постоји јединствено решење да ли у тим облицима долази до алтернације” (Зељић 2015: 35). 


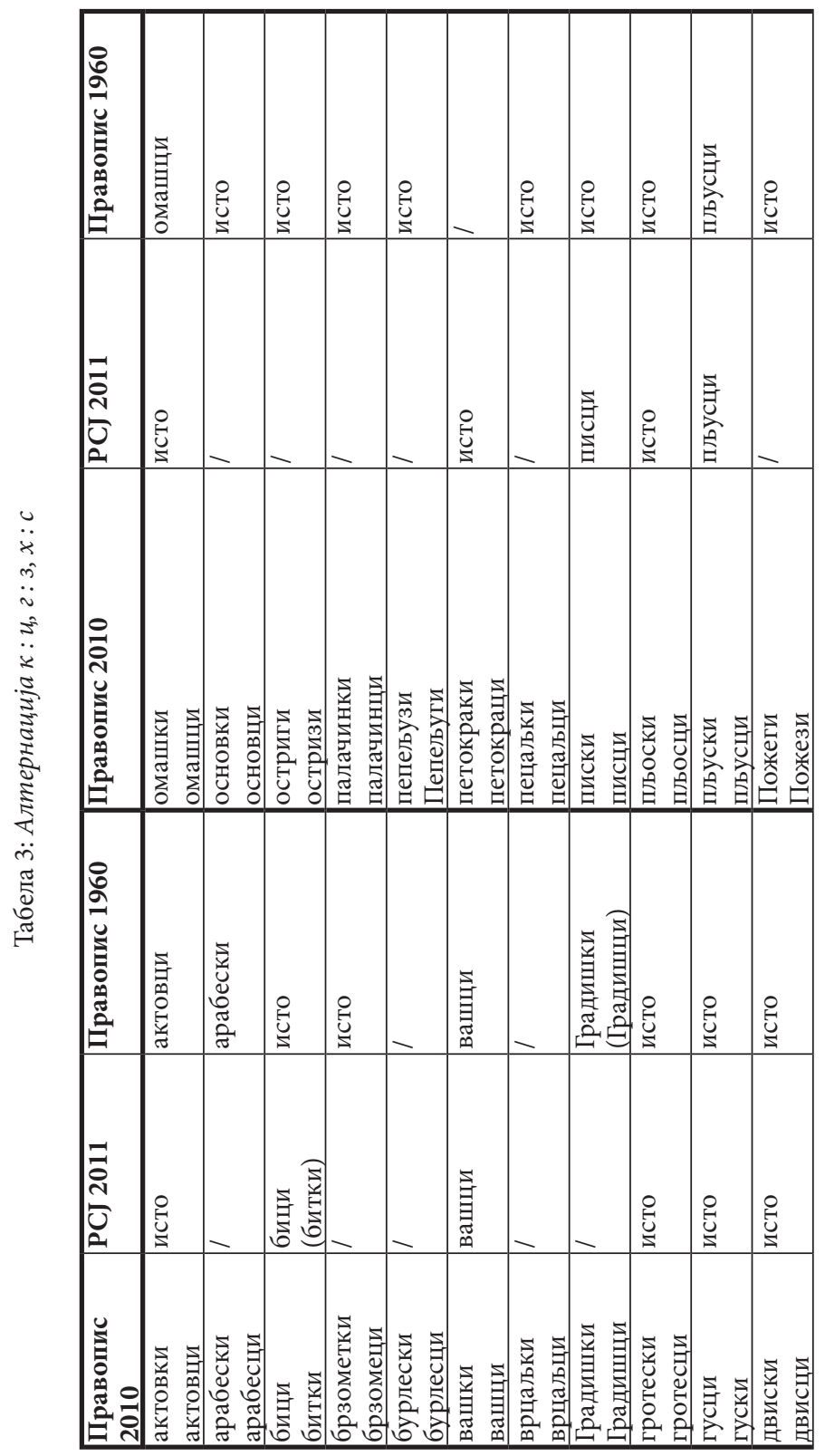




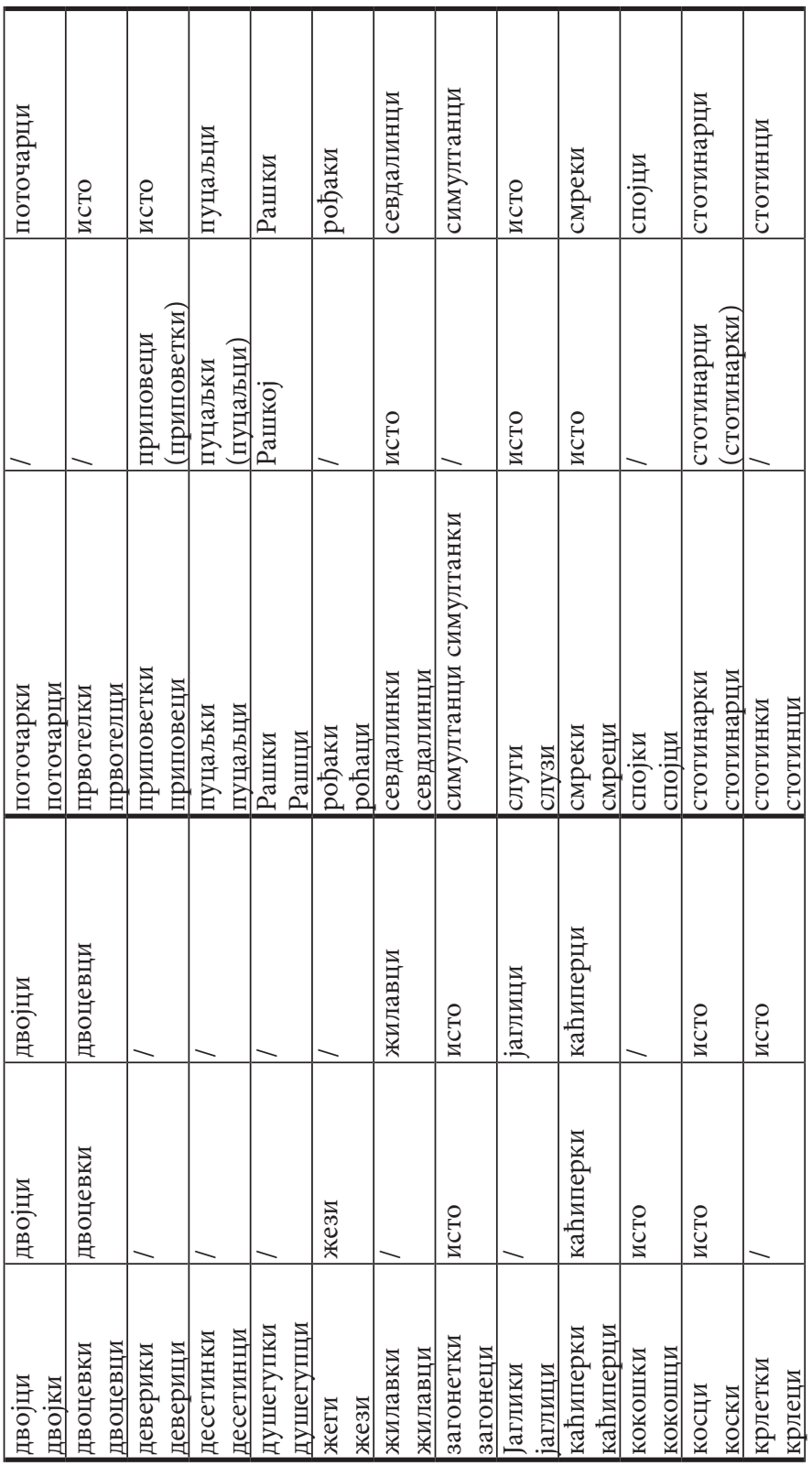




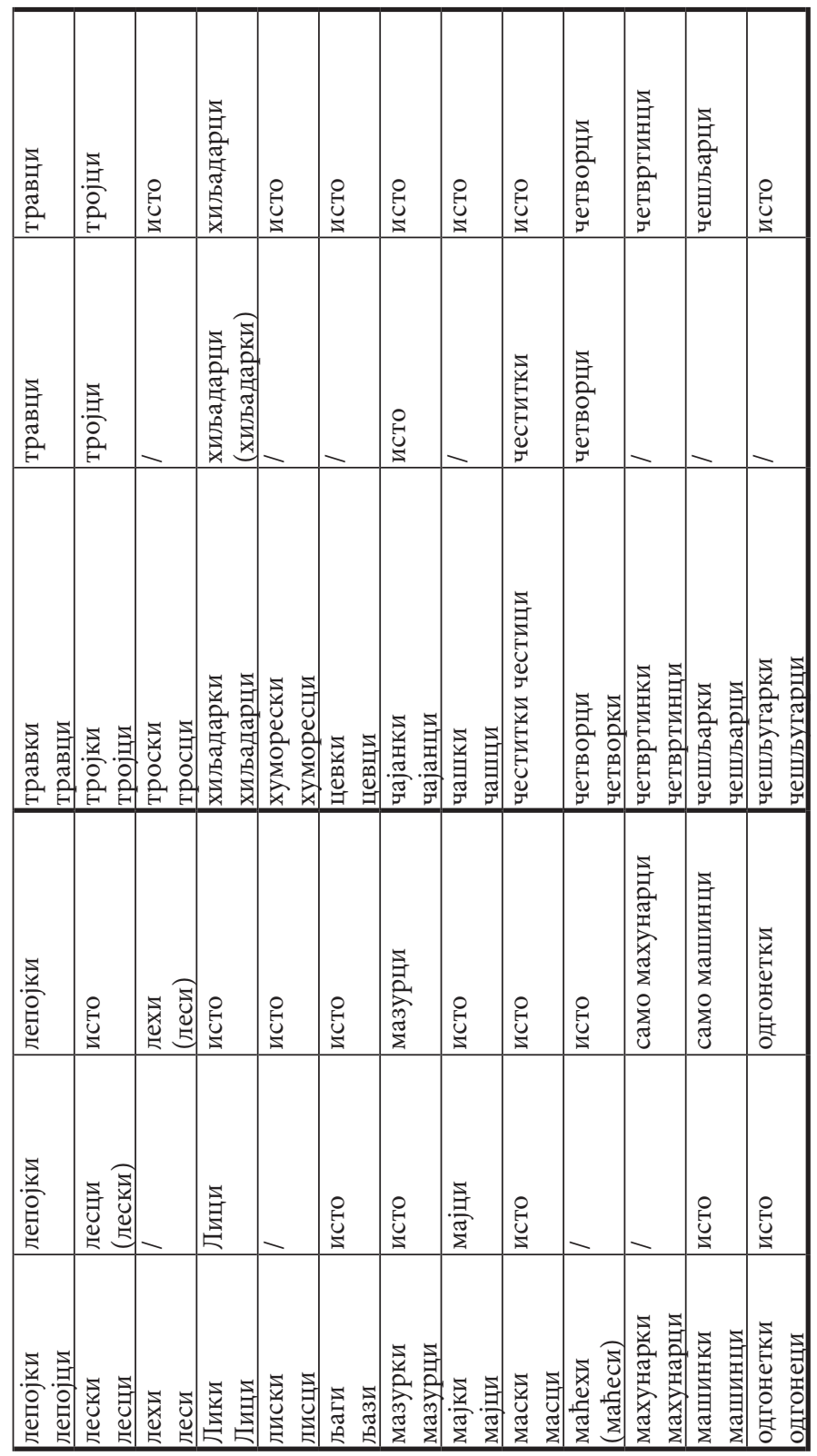


Правопис из 1960. бележи дупло мањи број дублета од П10 (само 35). Превагу углавном односе речи у којима је алтернација присутна: актовци, вашиц, двојизи, двоиевии, жилавии, јаглици, каћиперии, мазурии итд.,док су примери без алтернације малобројни: арабески, лепојки, одгонетки, Рашки, рођаки и смреки. Поједине примере треба прокоментарисати. У П10 јављају се дублети јаглищи / Јаглики, пепељьзи / Пепељуги, али са обележеном разликом у значењу. Ове именице могу бити и заједничке и властите. Ако су властите, алтернација није присутна, а у заједничкој је обавезна. У примерима мајки / мајци и гуски / гусии постоји такође значењска разлика. Мајки је датив именице ма́јка, која има значење бака или свекрва, док је мајци датив именице ма̂јка, у значењу мати. Облик гуски користи се у метафоричном значењу 'глупа ограничена женска особа', док облик гусии има примарно значење ('врста птице пловуше'). Именице лепојки, Рашки и рођаки наведене су само у овом облику, што је разумљиво, ако имамо у виду да се алтернација $\kappa: u, z: 3$ и $x: c$ не јавља у топонимима и у „суфиксалним изведеницама на -ка које значе жива бића" (Пипер-Клајн 2013: 85). Поменућемо и то да у П60 постоје примери који су у обележени као потпуно равноправни ликови, док су у П10 они наведени уз неко обележје: равноправни су Лики/Лиии, маћехи/маћеси, честитки/честиии, док се у П10 облици Лики и честици означавају као ретки, а маћеси се наводи у загради.

Број дублетних облика значајно је мањи и у РСJ, а разлог томе је што се многи примери не јављају као одреднице у речнику. Од 25 примера дублетних облика, само код неколико је једном облику дата предност (бици, лесии, приповеци, пуцаљки, стотинарии и хиљадарии). Такође, неки примери су наведени и као једини могући, без дублетног облика: ващиц, двојич, двоцевки, жези, каћиперки, лепојки, Лици, писии, пљусии, травии, тројци, честитки и четвории. Занимљиво је да је за то- 
поним Лика као једини облик дат./лок. наведено Лици, што није у складу са општим правилом да у топонимима алтернација изостаје, међутим, оно што се мора узети у обзир јесте и говорна навика становника насељеног места, што овде може бити случај. Алтернација, изостаје и из примера лепојки и каћиперки вероватно јер означавају особу женског пола, али и из примера честитки, јер би дошло до поклапања са дат./лок. именице честица.

Анализирани примери показују изразито шаренило, а слични су и одговори испитаника у нашем истраживању. У испитиваним примерима ретко где је било једноличних одговора. Већина сматра да је у примерима двојка, коска, маска и чајанка у дат./лок. једн. присутна алтернација, док у речима десетинка, жега, загонетка, кокочка, палачинка, Пожега, пуиалка, рођака и слуга она изостаје. Чини се да се правило када се јавља алтернација, а када изостаје не може извести. Именица Пожега се уклапа у систем примера у којима нема алтернације jер је у питању топоним. Претпостављамо да је код именице рођака алтернација изостала јер је у питању именица која означава особу женског пола. За именицу загонетка можемо претпоставити да је исто као и са именицом честитка, а за остале примере објашњење можемо једино наћи или у језичком осећању говорника да алтернација утиче на значење речи или у аналогији према неким другим речима, или просто у несигурности, а можда чак и нагађању при употреби ових именица. Највећу неодлучност испитаници су показали код именица актовка и лепојка. Скоро исти број испитаника се одлучио за облик са алтернацијом и за облик без алтернације, што није било очекивано, посебно за именицу лепојка. Будући да означава особу женског пола, очекивали смо да ће превагнути облик лепојки. За већину наведених примера, иако можда отежавају говорницима, дублети су заправо неопходни, јер је тешко донети одлуку који облик изабрати када резултати показују овакву слику. 
Велики број дублетних облика, али и других именица у којима ова алтернација изостаје је разумљив, „нарочито када су у питању речи које су скоро ушле у наш језик. Оне које смо раније примили прилагодиле су се правилима домаћих речи” (Стевановић 1986: 132).

Табела 4: Истраживање - алтернација $\kappa: u, 2: 3, x: c$

\begin{tabular}{|l|l|l|l|}
\hline \multicolumn{1}{|c|}{$\begin{array}{c}\text { Облици } \\
\text { алтерн. }\end{array}$} & $\begin{array}{c}\text { Број одговора } \\
(144)\end{array}$ & \multicolumn{1}{|c|}{$\begin{array}{c}\text { Облици } \\
\text { без алтерн. }\end{array}$} & $\begin{array}{c}\text { Број одговора } \\
(144)\end{array}$ \\
\hline актовци & $61(42,5 \%)$ & актовки & $83(57,5 \%)$ \\
\hline двојци & $134(93 \%)$ & двојки & $10(7 \%)$ \\
\hline десетинци & $16(11 \%)$ & десетинки & $128(89 \%)$ \\
\hline жези & $24(16,5 \%)$ & жеги & $120(83,5 \%)$ \\
\hline кокошци & $31(21,5 \%)$ & кокошки & $113(78,5 \%)$ \\
\hline косци & $18(12,5 \%)$ & коски & $126(87,5 \%)$ \\
\hline лепојци & $66(46 \%)$ & лепојки & $78(54 \%)$ \\
\hline масци & $92(64 \%)$ & маски & $52(36 \%)$ \\
\hline палачинци & $39(27 \%)$ & палачинки & $105(73 \%)$ \\
\hline Пожези & $17(12 \%)$ & Пожеги & $127(88 \%)$ \\
\hline рођаци & $51(35,5 \%)$ & рођаки & $93(64,5 \%)$ \\
\hline слузи & $28(19,5 \%)$ & слуги & $116(80,5 \%)$ \\
\hline чајанци & $117(81 \%)$ & чајанки & $27(19 \%)$ \\
\hline загонеци & $50(35 \%)$ & загонетки & $94(65 \%)$ \\
\hline пуцаљци & $11(7,5 \%)$ & пуцаљки & $133(92,5 \%)$ \\
\hline
\end{tabular}

Алтернација $о: e$

Алтернација која бележи највећи број дублетних облика свакако је алтернација $о$ : e. У правописном речнику јавља се 97 именица које имају двојаке облике искључиво у двема категоријама: инструменталу именица мушког рода и у присвојним придевима на -ов, односно -ев. Већина именица изведена је суфиксом -ар или се завршава на ову групу (резервоар), али се јављају и друге: гонител, густиш, даскаш, пиринач, плашт и сл. 


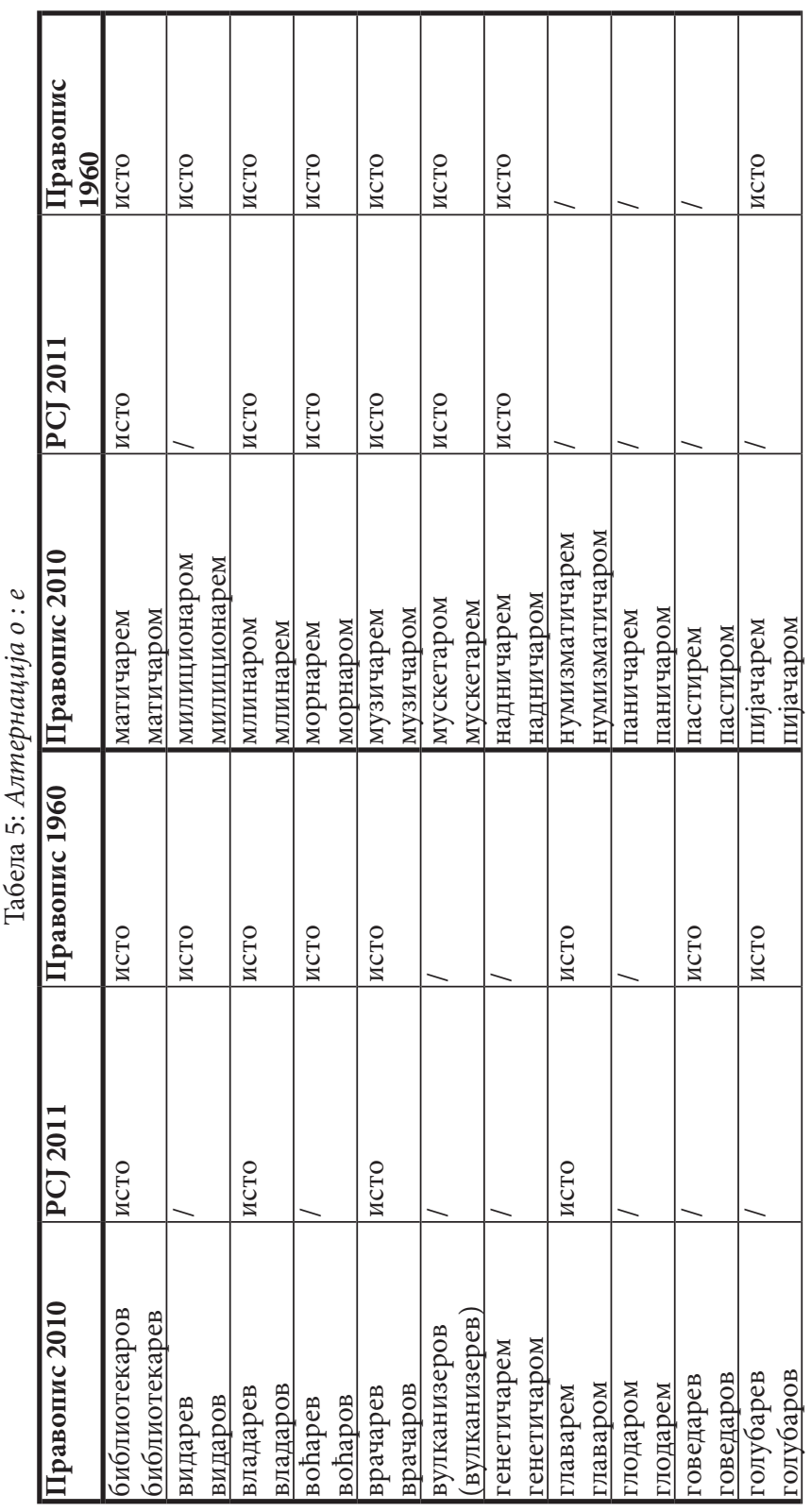




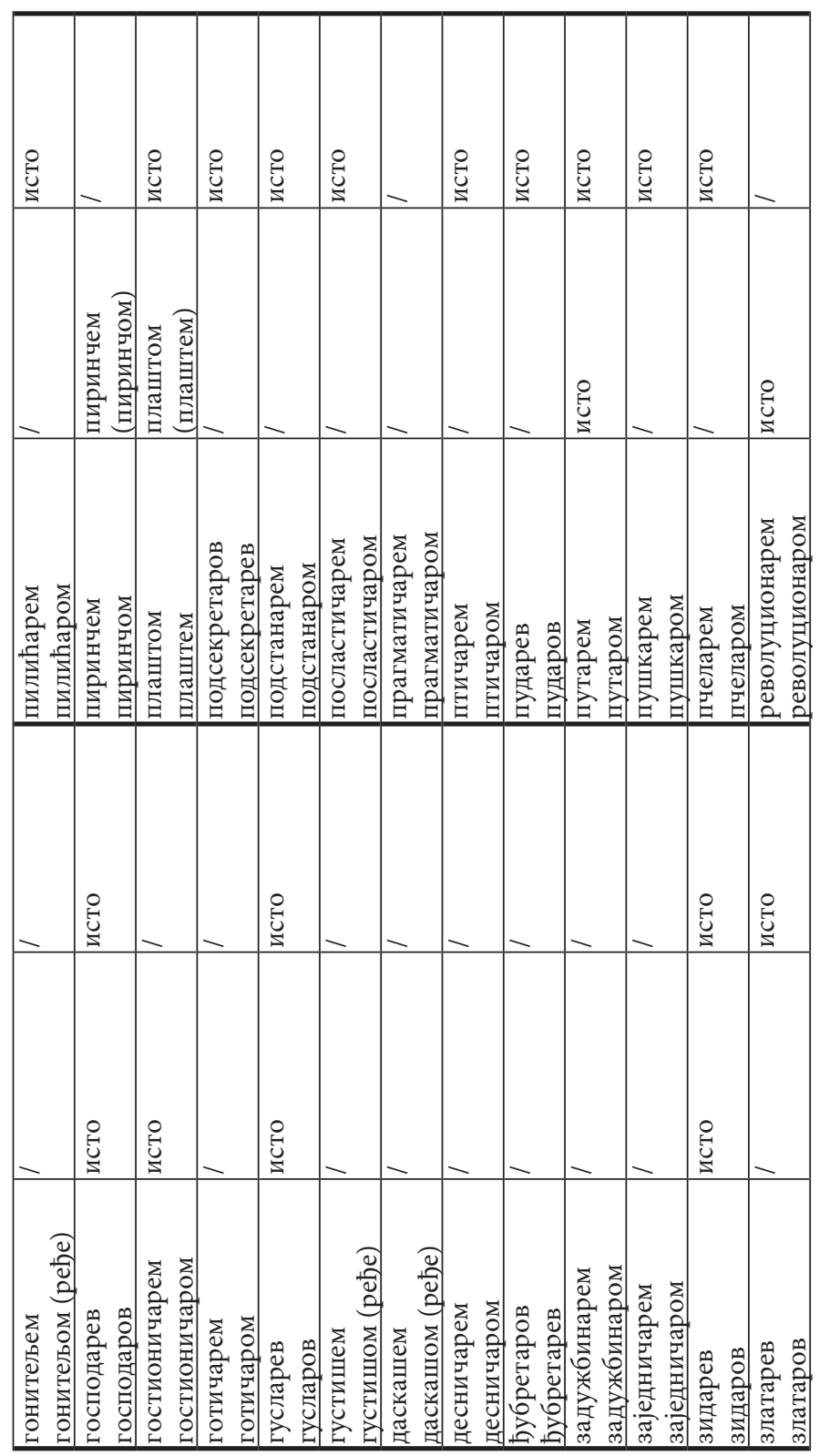




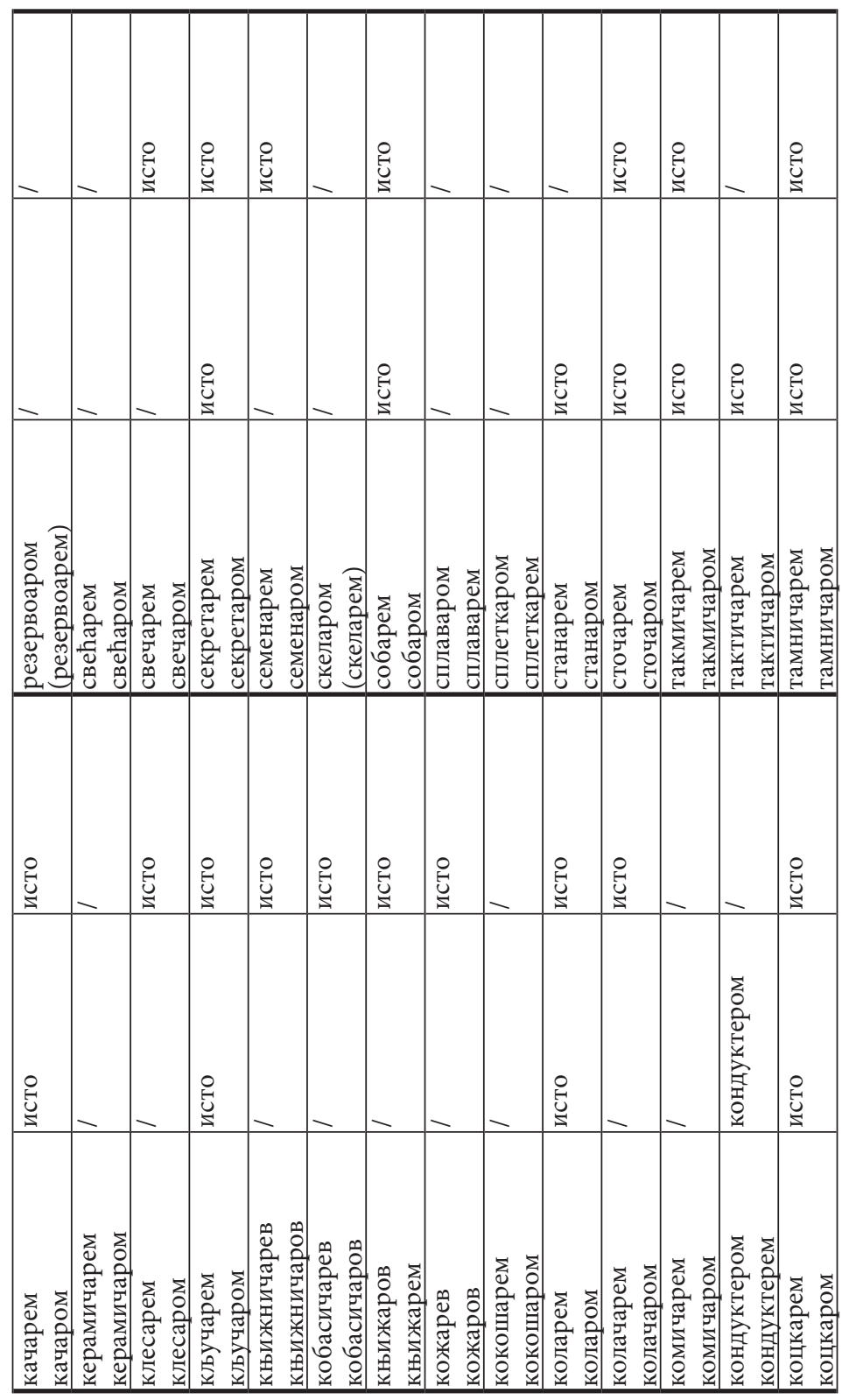




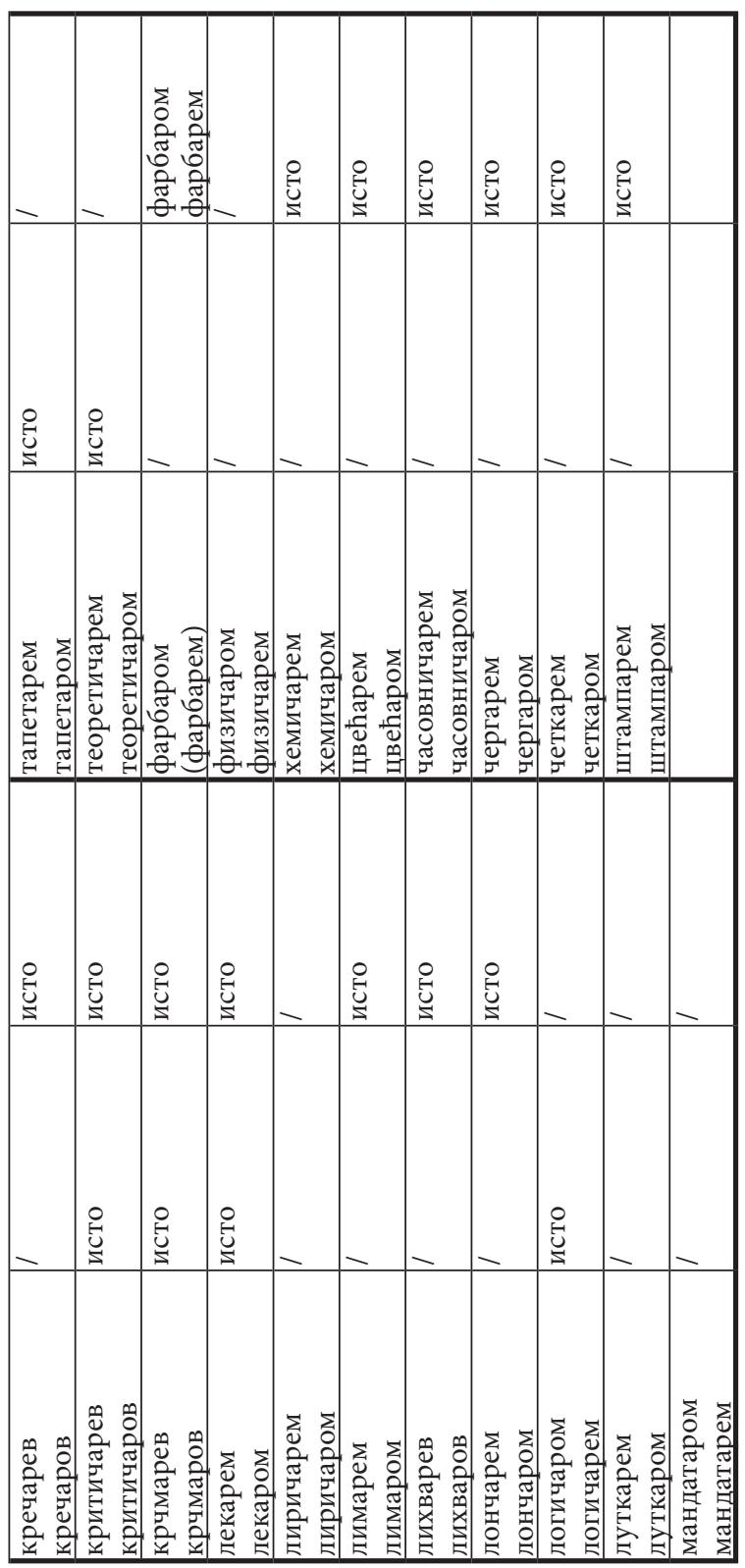


Промена $о$ у $е$ је историјска гласовна промена која се вршила у периоду када је у српском језику било више меких сугласника. Ако се основа завршавала меким гласом, $o$ је обавезно прелазило у $е$. „Поред данашњих

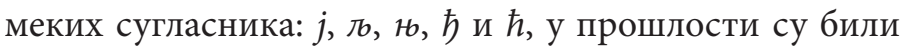
меки и остали предњонепчани сугласници: $u, u$, као и групе жд и $u m$, а гдекад и сугласник $p$. Иза тих сугласника дакле, није могао стајати самогласник o, него је прелазио у $е$ " (Стевановић 1986: 118). Остаци те мекоће задржали су се и у савременом језику, што се најбоље види у колебању при избору наставка -ом или -ем, односно суфикса -ов или -ев. У Правопису из 2010. јављају се и примери који су, навођењем у загради, обележени као ретки: вулканизерем, гонитељом, густишом, даскашом, резервоарем, скеларем и фарбарем. Именице гонитель, густиш и даскаш завршавају се предњонепчаним сугласницима (а глас љ је и мек), тако да је избор наставка -ем природан. Именица вулканизер као примарни има наставак -ом, јер се у слогу испред већ налази $e$, па долази до разједначавања, а исто је и са именицом резервоар - резервоаром. Иако се $e$ не налази у слогу испред наставка, оно се у овој речи већ јавља у два слога, тако да би наставком -ем дошло до нагомилавања истог вокала. Зашто су облици скеларем и фарбарем обележени као ређи, не можемо са сигурношћу тврдити. У П60 и у РСЈ готово да нема одступања у наведеним примерима. Неке именице се не могу наћи или нису наведени облици у којима би се могла пратити алтернација, али они примери који се јављају у сва три приручника обрађени су на скоро исти начин. У П60 именица фарбар у инстр. једн. има два равноправна облика, док је у П10 фарбаром примарни облик. Именица кондуктер у РСЈ у инстр. једн. има само један облик - кондуктером. Наставак -ем не долази у обзир, 
претпостављамо, опет због $e$ у претходном слогу. Такође, и код именица пиринач и плашт један облик је обележен као примаран - пиринчем због предњонепчаног $ч$ и плаштом због тврдог сугласника $m$.

И резултати нашег истраживања показују разноликост. Правилност у давању одговора није било могуће утврдити, осим у појединачним примерима. Занимљиво је да су се у свим примерима где је требало од именице извести присвојни придев, испитаници у већини одлучивали за суфикс -ев, док су у промени облика оба наставка била заступљена (табела 6). За наставак -ом опредељивали су се код именица кондуктер, плашт, резервоар, секретар и станар. Претпостављамо да је код наведених именица језичко осећање ишло, како смо већ наводили, у правцу „разједначавања”. Именица плашт се завршава тврдим гласом, а за именицу станар можемо само претпоставити да је дошло до утицаја речи која јој је претходила у анкети (секретар). Иако се наводи да „именице на р претежно имају -ом, али некад и -ем” (Пипер-Клајн 2013: 76), видели смо да се то не може утврдити као правило. 


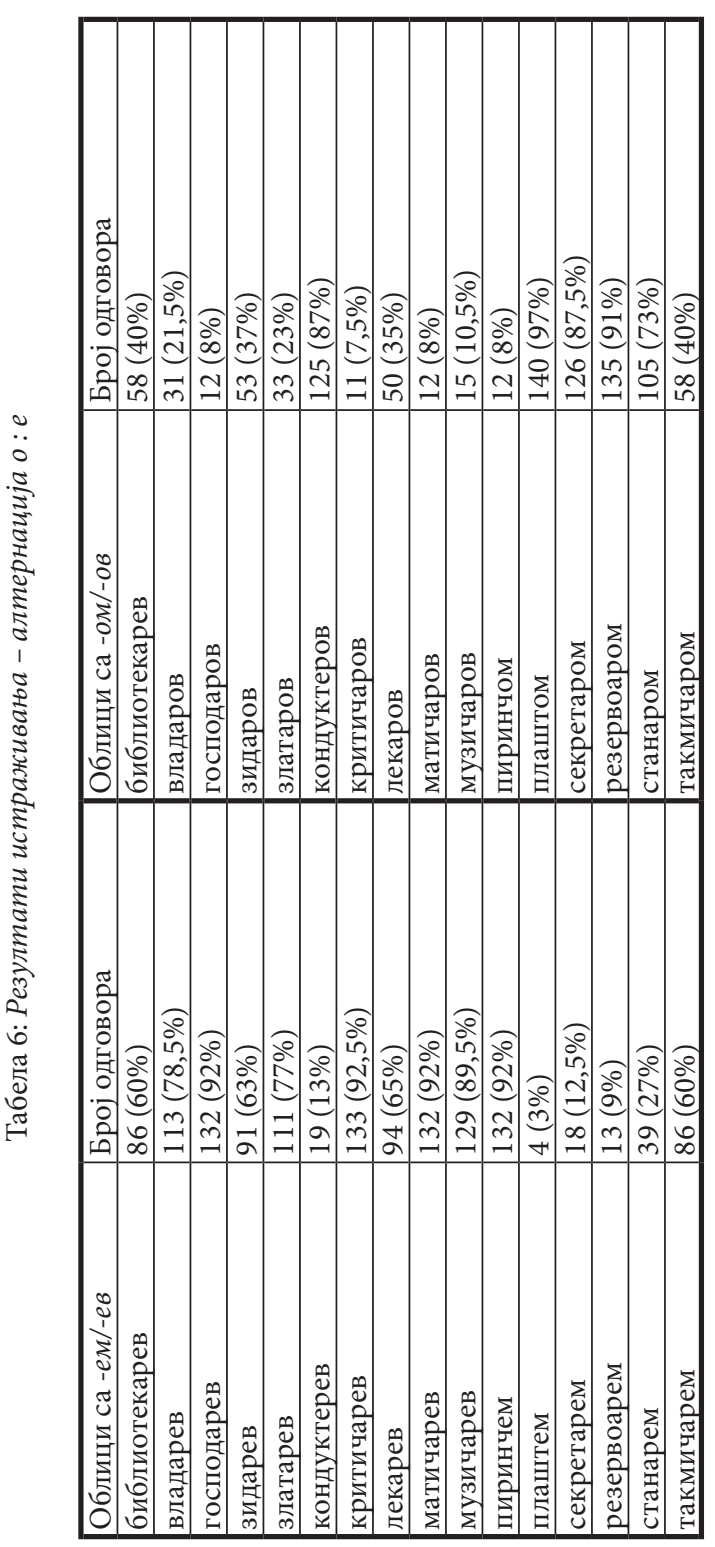


Будући да је дублетизам код ове алтернеција (o : e) највише изражен, свођење двојаких облика на један показује се као тежак задатак. Ипак, поједини примери (плашт, кондуктер и резервоар) показују тенденцију укидања једног члана, односно, издвајања једног облика као примарног.

\section{Алтернација $a: \varnothing$}

Непостојано $a$ је такође историјска гласовна промена која је узрокована вокализацијом некадашњег полугласника у јаком и губљењем тог гласа у слабом положају, због чега се то $а$ у неким облицима јавља, а у неким не. П10 бележи 35 примера код којих се у номинативу једнине могу јавити облици са уметнутим $a$, али и без њега. 


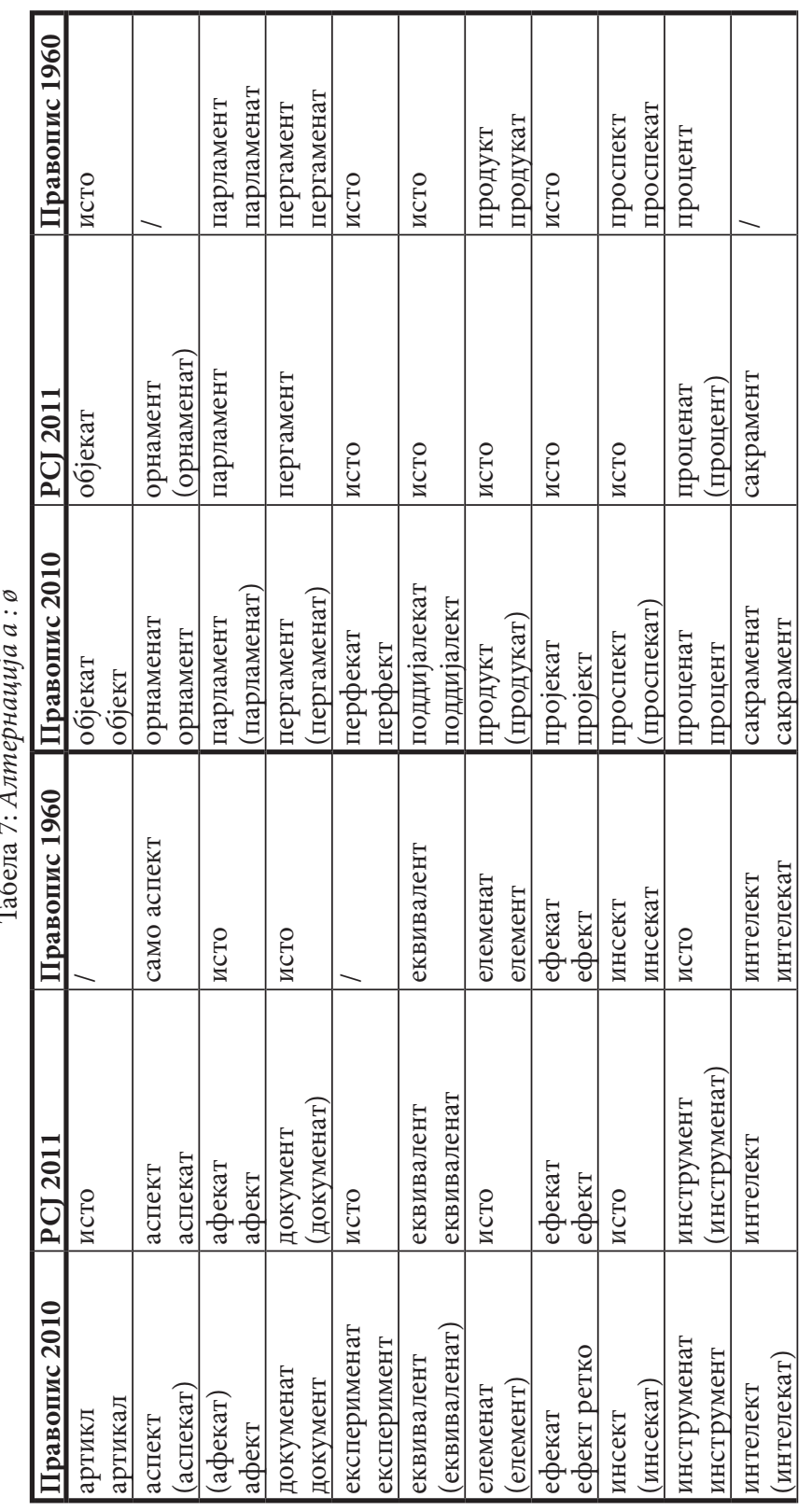




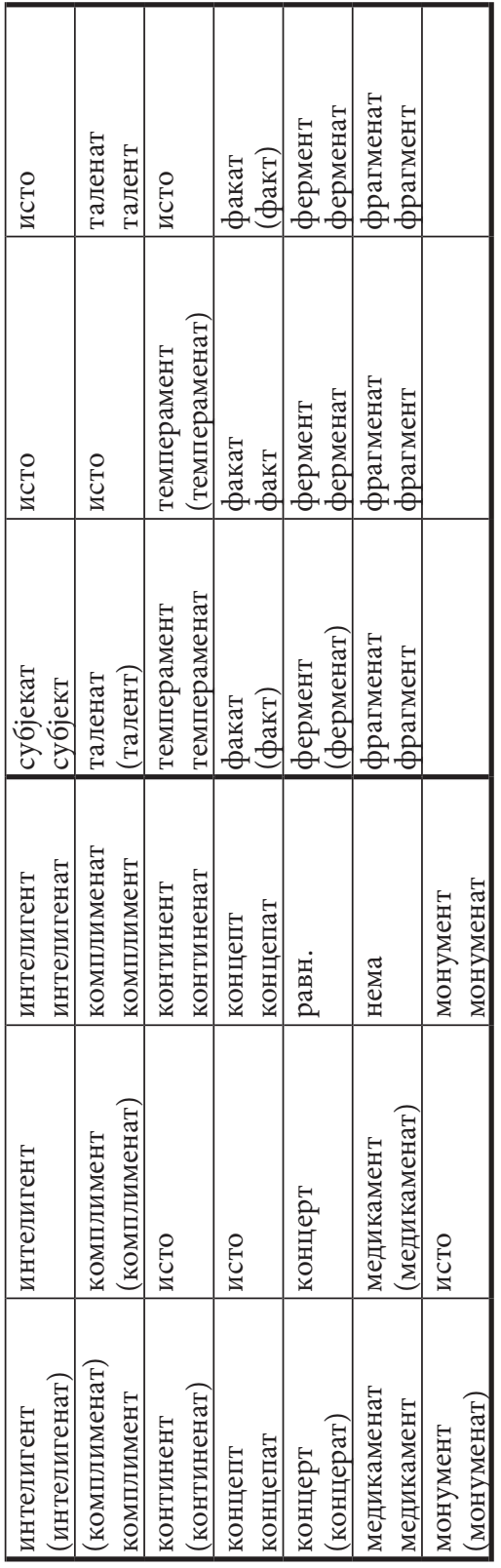


Сви издвојени примери су речи страног порекла који се у номинативу завршавају на сугласничку групу -нm, $-\kappa m,-\kappa л$ и -nm, те је због тога између два сугласника уметано $a$ које је требало да олакша изговор ових речи. „У старијем језику реч се није могла завршавати на два су-

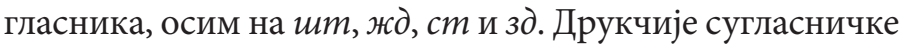
групе испрва су разбијане непостојаним а, али под налетом многобројних туђица ово ограничење за финалне сугласничке групе престало је да важи" (Пипер-Клајн 2013:39). У говору, а како бележи и П10, могу се наћи обе варијанте, с тим што се у већини примера једна издваја као примарна: апсект, афект, еквивалент, елеменат, ефбекат, инсект, интелект, интелигент, комплимент, континент, концепт, концерт, парламент, пергамент, продукт, проспект, таленат, факат.

У П60 издвајање неког облика као примарног изостаје. За разлику од П10, сви наведени облици су потпуно равноправни. Једино се именице процент, еквивалент и аспект наводе само у овом облику, без уметнутог a. Разлика између двају правописа је евидентна - у већини именица данас се један облик усталио као бољи или фреквентнији, док други остаје по страни, што је и природни пут дублетних облика. Решења у РСЈ стоје између П60 и П10. У већини примера РСЈ и П10 се поклапају, док су други у РСЈ обележени као равноправни дублети. У неким случајевима издваја се само један облик: интелект, интелигент, концерт, парламент, пергамент, сакрамент; или се једном облику даје предност: документ, инструмент, комплимент, медикамент, објекат, орнамент, проценат, темперамент.

За разлику од приручника, одговри испитаника дали су једноличну слику. Према нашим резултатима $a$ се не јавља у вишесложним речима, па ће бити: документ, експеримент, елемент, инструмент, комплимент, конти- 
нент, парламент и пергамент. Облике са $а$ написао је у неким примерима веома мали број испитаника, док је у неким био заступљен само облик без $а$. Слично је и са двосложним речима инсект и концерт. Већина, а за концерт сви испитници, определила се за облик без $а$. Са друге стране именице пројекат, проценат, субјекат и таленат најчешће се јављају у овом облику. Разлог овоме може бити и број слогова у речи, али не можемо рећи засигурно. Претпостављамо да је облик субјекат превладао због термина који се јавља у већини граматика.

Табела 8: Резултати истраживаюа - алтернација а :

\begin{tabular}{|l|l|l|l|}
\hline \multicolumn{1}{|c|}{$\begin{array}{l}\text { Облик са } \\
\text { вокалом } a\end{array}$} & \multicolumn{1}{|c|}{ Број одговора } & \multicolumn{1}{|c|}{$\begin{array}{c}\text { Облик без } \\
\text { вокала } a\end{array}$} & Број одговора \\
\hline инструмент & $144(100 \%)$ & инструменат & $/$ \\
\hline инсект & $133(92,5 \%)$ & инсекат & $11(7,5 \%)$ \\
\hline експеримент & $144(100 \%)$ & експерименат & $/$ \\
\hline елемент & $144(100 \%)$ & елеменат & $/$ \\
\hline документ & $141(98 \%)$ & докуменат & $3(2 \%)$ \\
\hline комплимент & $143(99,3 \%)$ & комплименат & $1(0,7 \%)$ \\
\hline континент & $144(100 \%)$ & континенат & $/$ \\
\hline концерт & $144(100 \%)$ & концерат & $/$ \\
\hline субјект & $1(0,7 \%)$ & субјекат & $143(99,3 \%)$ \\
\hline парламент & $143(99,3 \%)$ & парламенат & $1(0,7 \%)$ \\
\hline пергамент & $144(100 \%)$ & пергаменат & $/$ \\
\hline процент & $2(1,5 \%)$ & проценат & $142(88,5 \%)$ \\
\hline талент & $/$ & таленат & $144(100 \%)$ \\
\hline пројект & $3(2 \%)$ & пројекат & $141(98 \%)$ \\
\hline
\end{tabular}

Примери који илуструју ову алтернацију отварају највише простора за истицање једне варијанте као примарне или можда чак једине која би била у употреби. Ни у једном примеру који је обухваћен истраживањем није било колебања код испитаника, због чега би било могуће мање заступљен облик обележити као архаичан или можда нестандардан. Оно што може бити проблем, 
јесте несистемност ове појаве уметања вокала $a$ у финалну сугласничку групу - у којим случајевима се оно јавља, а у којим не. Свакако, додатна истраживања могла би дати одговор на ово питање.

\section{Сугласник $x$}

„Због посебне артикулације, и у вези с његовом акустичком природом, сугласника $x$ је у највећем делу српских и хрватских говора, поготову оних говора који се налазе у основици данашњег књижевног језика - нестало" (Стевановић 1986: 142). Глас $x$ ушао је у српски књижевни језик након Вукове реформе, тачније 1836. када га Вук бележи у тадашњем издању Пословииа и говори да би $x$ требало писати тамо где му је по пореклу место. Иначе, глас $x$ се не јавља у српским народним говорима, због чега је некад на његовом месту било $j$ или в или се $x$ губило без замене. Из данашње перспективе глас $x$ представља обавезан глас у фонтеском систему српског језика, јер има и морфолошку улогу. Због његовог статуса у књижевном језику и у народним говорима, јављају се дублетни облици. 


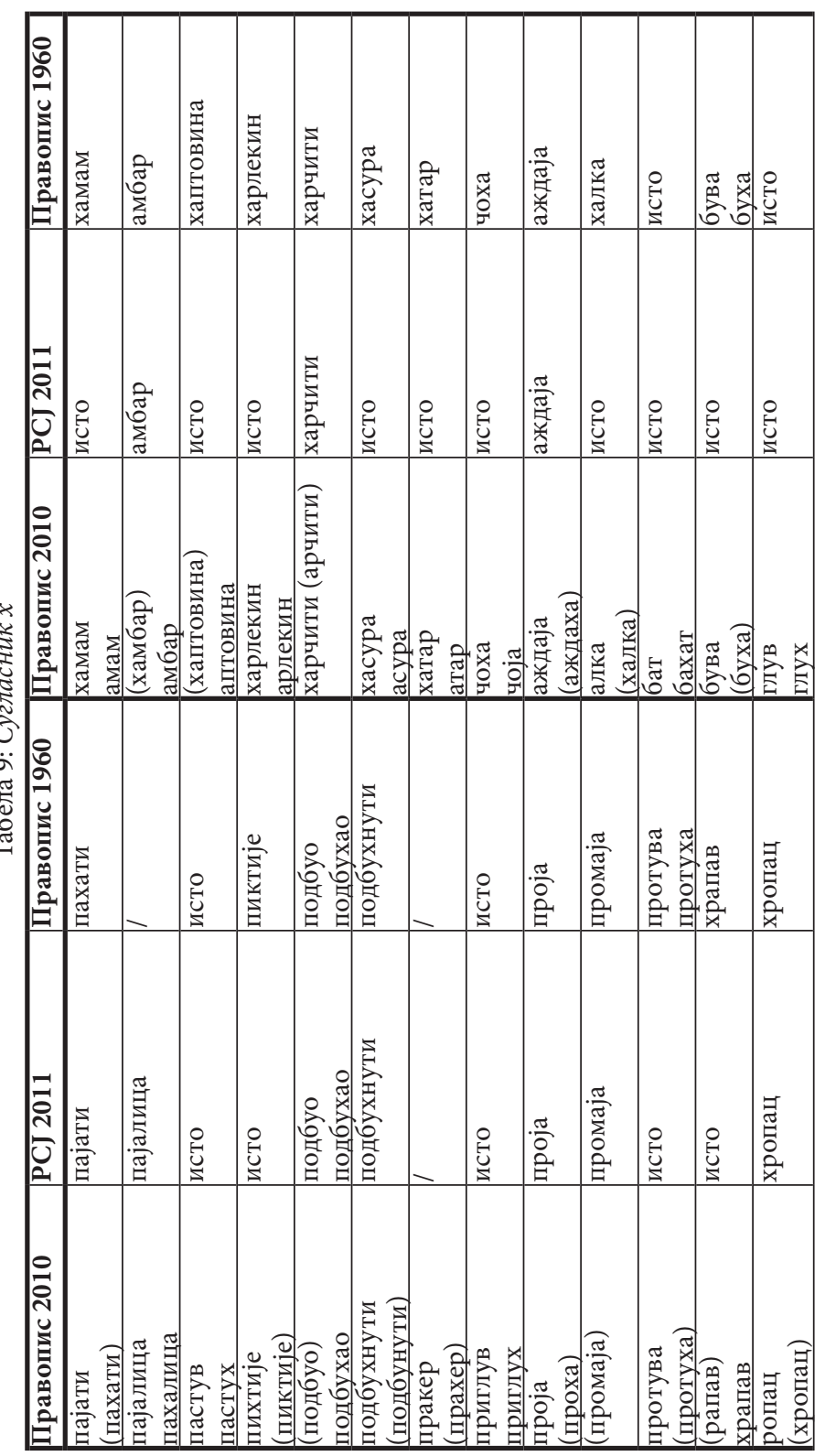




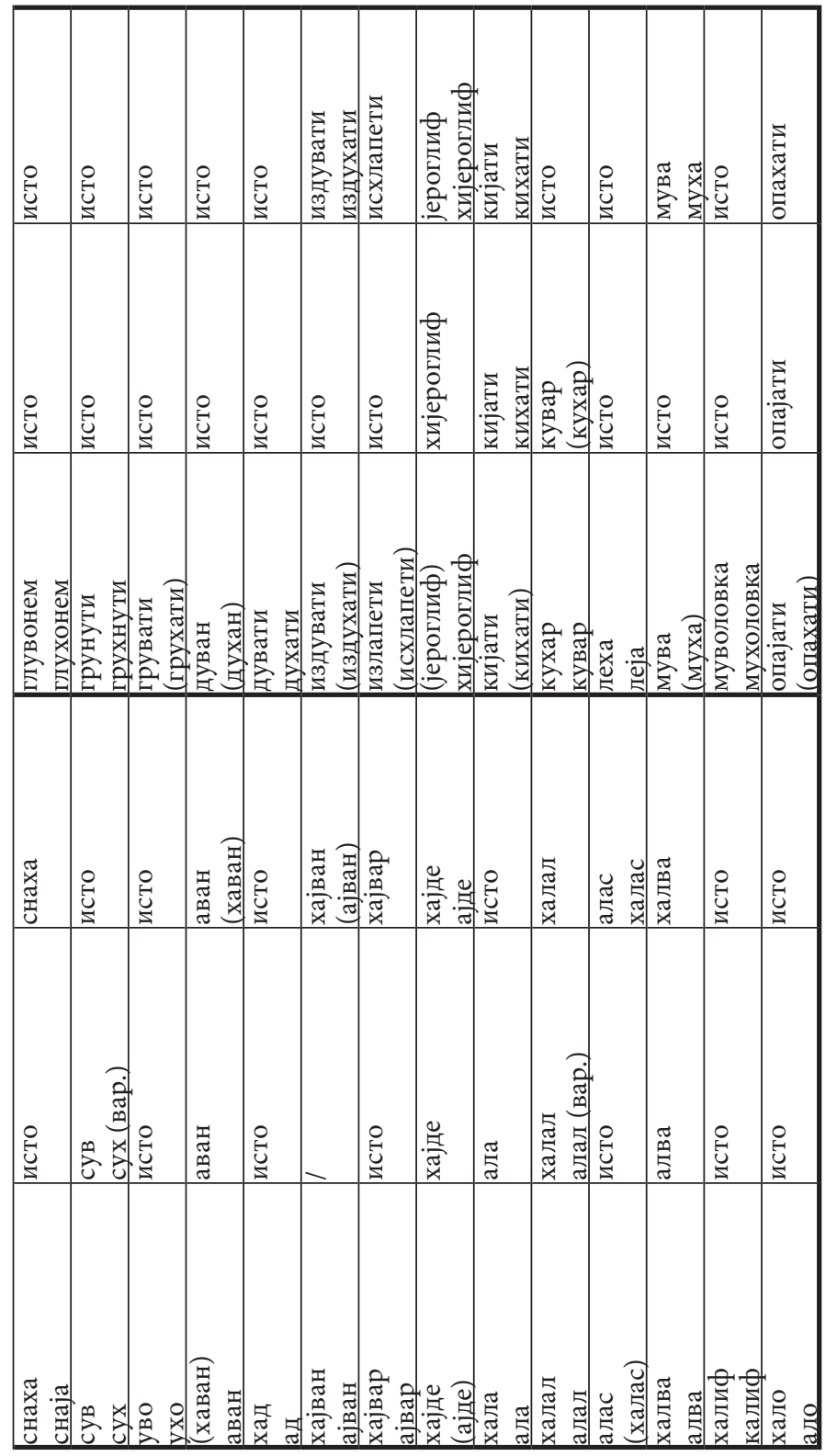


Наведени примери нису потпуно равноправни, већ се неки издвајају као примарни, док су други обележени као ређи или необични. Као необични или ређи издвојени су: пахати, пиктије, подбухао, подбухнути, пракер, протуха, рапав, хропаи, хаван, ајде, халас, хамбар, хаптовина, арчити, халка, буха, грухати, духан, издухати, исхлапети, јероглиф, кихати, муха и опахаmu. Поједини примери су територијално обележени, па се наводи да се облици проха и промаха јављају у муслиманским срединама, а облик аждаха је означен као регионалан. У примеру снаја/снаха постоји разлика сфери употребе. Један је одлика фамилијарног обраћања (снаја), док је други примеренији стандардном језику. Дакле, скоро половина речи нема равноправне дублетне облике, већ је један од њих обележен на неки начин. Међутим, у делу Правописа у ком се налазе правила, у тексту у вези са писањем $x$, могу се наћи само облици као што су: бува, мува, дувати, грувати, кувати, кувар, протува, дуван, мувар и ђинђува, а у речнику ове речи јављају се са дублетним формама. Разлог томе је следећи: „Додатну правописну пометњу 2010. године донела је појава правописног речника српског језика са правописно-граматичким саветником Милана Шипке. Наиме, Правописни речник се појавио пре Правописа српскога језика, па постоји неусклађеност око неких решења, што уноси додатну забуну" (Брборић 2016: 138).

У П60 дублетни облици су другачије обележени. Будући да је настајао у доба СФРЈ, било би очекивано да је више дублетних облика који су равноправни, међутим, и овде влада разноликост. Један број дублета обележен је као равноправан, док је код других само једна варијанта обележена као тачна: пиктије, подбухнути, проја, промаја, храпав, хропаи, снаха, халал, халва, хам, хамам, амбар, хаптовина, харлекин, харчити, хасура, чоха, аждаја, исхлапети, опахати. 
У наведеним примерима могу се издвојити неки који би из данашње перспективе изгледали архаично или регионално обојени (опахати, пиктије, хасура и сл.). Најзанимљивији су они у којима долази до размимоилажења П60 и П10. На пример у П60 се као једини или примарни облици јављају: исхлапети, халка, хаптовина, пахати и опахати, док је у П10 друга варијанта та која је примарна, односно она која се препоручује (излапети, алка, аптовина, пајати и опајати). Такође, у П60 се као бољи препоручују и облици хајвар и хајван, који би данас могли звучати необично. У РCJ постоје две варијанте наведених примера - или су означени као дублетни облици или се јавља само један. Ни у једном случају се не препоручује један више од другог, већ је само у два примера један од облика означен као варијанта: алал и сух. Речи код којих се јавља само један облик су: пајати, пајалии, подбухнути, проја, промаја, хропаи, аван, хајде, ала, алва, амбар, харчити, аждаја, хијероглиф и опајати. Имајући у виду наведене примере, можемо закључити да је РСJ донекле ближи оном што се може чути у говору.

Претходно наведену тврдњу могли бисмо допунити резултатима истраживања. Одговори испитаника су били готово истоветни. Речи дувати, ајвар, храпав, nроја и пихтије јављају се скоро искључиво у том облику. Занемарљиво мали број испитаника се опредељивао за облике (четворо од 144) пиктије, рапав и ајвар. Напоменућемо и то да су се сва четири одговора нашла међу основцима, па се треба запитати да ли су знали шта значе наведене речи или је избор био случајан. Између варијаната снаја и снаха, испитаници су се углавном одлучивали за први, а само два испитаника су заокружили слово испред оба облика. 
Табела 10: Резултати истраживана - сугласник $x$

\begin{tabular}{|l|l|l|l|}
\hline $\begin{array}{c}\text { Облик са } \\
\text { гласом } x\end{array}$ & Број одговора & $\begin{array}{c}\text { Облик без } \\
\text { гласа } x\end{array}$ & Број одговора \\
\hline духати & $/$ & дувати & $144(100 \%)$ \\
\hline пихтије & $140(97 \%)$ & пиктије & $4(3 \%)$ \\
\hline проха & $/$ & проја & $144(100 \%)$ \\
\hline снаха & $16(11 \%)$ & снаја & $128(89 \%)$ \\
\hline хајвар & $4(3 \%)$ & ајвар & $140(97 \%)$ \\
\hline храпав & $140(97 \%)$ & рапав & $4(3 \%)$ \\
\hline
\end{tabular}

Истраживање показује да би се и у овом случају поједини дублети могли свести на један облик, па бисмо, тако добили само ајвар, проја, промаја, дувати и сл. Неки од ових примера су већ у Правопису обележени као обичнији и чешћи, што даје могућности за њихово даље нормирање.

\section{Закључак}

Имајући у виду шаренолику слику коју је показало спроведено истраживање, може се закључити да је свођење дублетних облика на један облик у појединим случајевима готово немогуће. Осим тога, чини се да је фонетска норма у неким случајевима, према анализираним приручницима, ишла неочекиваним путем уместо смањења, дошло је до повећања дублетних облика, поготову код алтернација $\kappa: \mathcal{u}, 2: \mathcal{*}, x: \mathcal{u}$ и $\kappa: \mathcal{u}$, $2: 3, x: c$. У односу на старије стање (П60) број дублета смањио се само код алтернације $a: \emptyset$, али не тако што је један од облика укинут, већ тако што је једном дата предност. При изговору гласа $x$ и алтернацији $o: e$ ситуација се није много променила у односу на старије стање - избор облика је и даље разноврстан.

Међутим, анкетирање испитаника показало је да у појединим случајевима постоји оправдан разлог да се код појединих примера један облик издвоји као 
примаран. Такви случајеви јављају се у алтернацији $a$ : $\varnothing$ и при изговору гласа $x$. Као што резултати анкете показују, готово сви испитаници су се једногласно опредељивали за један облик. Овде би се могли сврстати и појединачни примери осталих алтернација: шункица, двојци, плаштом и др. који имају висок проценат код испитаника. Целокупна слика показује да је нормирање дублетних облика тежак посао и да је за њега потребно још додатних истраживања која би обухватала и више испитаника, али и друге изворе. Оно што не треба заборавити јесте и сам језик и његова природа. Његов спонтани развој у највећем броју случајева довешће до тога да се једна варијанта издвоји као примарна, док ће друга остати на неки начин обележена. Међутим, важно је да нормативисти тај развој прате и делају на време како би свака евентуална промена, колико је то могуће, ишла у корист како говорницима тако и систему српског језика.

\section{ЛИТЕРАТУРА}

Брборић 2016: В. Брборић, О српском правопису, Београд: Друштво за српски језик и књижевност Србије.

ЕРСJ: Електронски речник српског језика, http://www. srpskijezik.com, приступљено 12. 1. 2020.

Зељић 2015: Г. Зељић, Правописни аспект датива и локатива једнине именица женског рода на -ка, -гa, -xa, 3борник Матице српске за филологију и тингвистику, LVIII/2, Нови Сад: Матица српска, стр. 35-47.

Јокановић Михајлов 2012: Ј. Јокановић-Михајлов, Прозодија и говорна култура, Београд: Друштво за српски језик и књижевност Србије.

Пипер-Клајн 2013: П. Пипер, И. Клајн, Нормативна граматика српског језика, Нови Сад: Матица српска.

Правопис 2010: М. Пешикан, Ј. Јерковић, М. Пижурица, Правопис српскога језика, Нови Сад: Матица српска.

Правопис 1960: Правопис српскохрватскога книжевног језика, Нови Сад: Матица српска. 
PCJ 2011: Речник српскога језика, Нови Сад: Матица српска.

Стакић 2010: М. Стакић, Морфо(но)лошке теме, Београд:

Друштво за српски језик и књижевност Србије.

Стевановић 1986: М. Стевановић, Савремени српскохрватски језик, Београд: Научна књига.

Ћорић 2009: Б. Ћорић, Лингвомаргиналије, Београд: Друштво за српски језик и књижевност Србије.

Ljubica D. Vesić

\section{ON THE USE OF PHONETIC DOUBLETS IN MODERN LANGUAGE}

\section{Summary}

Doublet forms are a common phenomenon in the phonetic system of the Serbian language just like in other language subsystems. They usually occur within voice changes I alternatives, but also in relation to the pronunciation of the $\mathrm{H}$ voice. The Serbian Language Orthography by Matica Srpska (2010), mentions as doublets some forms that a certain number of native speakers of the Serbian language would certainly consider unusual and perhaps even archaic (ajvar - hajvar, koncerat koncert). Furthermore, the large number of doublets does not necessarily make it easier for speakers to choose a certain form. Often, the situation is just the opposite, and hesitation and uncertainty occur in speech. Therefore, the main aim of the paper is to show the categories in which doublet forms occur "as a rule" and to re-examine their position in the system: whether in all the above examples (koncert - koncerat, barakica - baračica, vaški vašci) it is justified to have two forms and whether it is possible to simply declare one form incorrect, as well as how to determine which forms should be given priority or considered as the only right one in modern speech.

Keywords: phonetics, voice alternatives, voice changes, doublets, Serbian language norm. 